\title{
PERBANDINGAN KERUSAKAN AKTUAL DAN PRAKIRAAN PADA BANGUNAN TEMBOK TANPA PERKUATAN AKIBAT GEMPA
}

\author{
Jafar $^{1, *)}$, Sarwidi $^{2}$, Mochamad Teguh ${ }^{3}$, Fitri Nugraheni ${ }^{4}$ \\ ${ }^{1, *}$ Jurusan Teknik Sipil, Fakultas Teknik Sipil dan Perencanaan, Universitas Islam Indonesia \\ Email: jafar@uii.ac.id \\ ${ }^{2}$ Jurusan Teknik Sipil, Fakultas Teknik Sipil dan Perencanaan, Universitas Islam Indonesia \\ Email: sarwidi@uii.ac.id \\ ${ }^{3}$ Jurusan Teknik Sipil, Fakultas Teknik Sipil dan Perencanaan, Universitas Islam Indonesia \\ Email: m.teguh@uii.ac.id \\ ${ }^{4}$ Jurusan Teknik Sipil, Fakultas Teknik Sipil dan Perencanaan, Universitas Islam Indonesia \\ Email: fitri.nugraheni@uii.ac.id
}

\begin{abstract}
On April 18, 2018, an earthquake hit Banjarnegara Regency, Central Java. The quake was measured M4.4 at a depth of $4 \mathrm{~km}$ and caused damages to buildings in several villages within Kalibening District. Predicting future earthquake events is difficult. However, it is possible to estimate the potential damage caused by an earthquake event. FEMA has developed a methodology called HAZUS to evaluate the potential loss and damage caused by earthquakes. This study compared the actual damage to buildings subjected to the 2018 Banjarnegara earthquake with the estimated damage to buildings obtained using HAZUS. The real damage is obtained from the field survey, while the estimated damage is obtained from the HAZUS modeling. The object of this research is the unreinforced masonry low-rise buildings (URML) in Kasinoman Village, one of the villages that suffered the most subjected to the 2018 Banjarnegara Earthquake. The result of this study indicates the actual damage has a higher mean damage ratio (20.40\%) compared to the estimated damage (11.66\%). HAZUS is developed according to the performance and experimental data of the buildings in the US; therefore, it might not be compatible with the building in Indonesia, especially surveyed buildings in Banjarnegara. The buildings in the US fulfilled the earthquake-resistant building provision, while the surveyed buildings did not.
\end{abstract}

Keywords: earthquake, building damages, unreinforced-masonry, HAZUS

\section{LATAR BELAKANG}

Gempa bumi merupakan salah satu ancaman bencana yang paling sering terjadi di Indonesia. Gempa bumi dapat didefinisikan sebagai sebuah getaran di permukaan bumi yang diakibatkan oleh pelepasan energi secara tiba-tiba akibat pergerakan lempeng bumi atau letusan gunung api (Widodo, 2012). Indonesia menjadi salah satu negara dengan riwayat panjang kejadian gempa karena terletak di antara pertemuan Lempeng Eurasia, Lempeng Indo-Australia, serta Lempeng Pasifik. Lempeng-lempeng tektonik ini bergerak ke arah tertentu dengan kecepatan tertentu sehingga menghasilkan tumbukan yang berkibat pada terjadinya gempa bumi. Gambar 1. menunjukkan gambaran mengenai kejadian gempa di Indonesia, khususnya Pulau Jawa, yang terjadi antara tahun 1965-2019. Satu hal yang perlu digarisbawahi adalah gempa tidak menyebabkan korban jiwa secara langsung. Sebagian besar korban jiwa yang timbul dalam kejadian bencana gempa bumi, disebabkan oleh reruntuhan bangunan yang kemudian menimpa penghuni di dalamnya. Spence (2004) menyatakan bahwa lebih dari 75\% korban jiwa dalam kejadian gempa bumi di seluruh dunia antara tahun 19501999 disebabkan oleh reruntuhan bangunan. Pada penelitian tersebut dijelaskan bahwa bangunan-bangunan tersebut merupakan 
bangunan yang tidak menerapkan prinsip bangunan tahan gempa.

Gempa bumi terjadi secara tiba-tiba tanpa ada tanda-tanda pasti yang mendahuluinya. Oleh karena itu, sulit memperkirakan kejadian sebuah gempa. Namun, hal ini tidak berarti bahwa tidak ada langkah-langkah yang bisa dilakukan untuk mengurangi dampak akibat sebuah gempa bumi. Dalam manajemen bencana, upaya pengurangan dampak bencana akan lebih optimal apabila dilakukan pada fase pra-bencana. Tentunya, ini sangat relevan dengan konteks gempa bumi karena kejadiannya yang tiba-tiba. Hal ini juga sejalan dengan gagasan yang dituliskan dalam Sendai Framework for Disaster Risk Reduction 2015-2030 dimana dalam konferensi dunia tersebut ditentukan 4 prioritas aksi untuk mencegah dan mengurangi risiko bencana (IFRC, 2015). Empat aksi tersebut adalah (i) memahami risiko bencana; (ii) memperkuat tata kelola risiko bencana untuk mengelola risiko bencana; (iii) berinvestasi dalam pengurangan bencana untuk ketahanan dan; (iv) meningkatkan kesiapsiagaan bencana untuk respon yang efektif, dan untuk "Membangun Kembali dengan Lebih Baik" dalam pemulihan, rehabilitasi, dan rekonstruksi.

Memperkirakan dengan pasti kejadian gempa di masa mendatang memang sangat sulit, jika tidak ingin dikatakan mustahil. Namun demikian, memperkirakan potensi kerusakan dan kerugian akibat gempa yang akan terjadi di masa mendatang masih memungkinkan untuk dilakukan. Dalam manajemen bencana aktivitas ini disebut dengan asesmen risiko bencana (disaster risk assessment).
Di beberapa negara yang rentan terhadap ancaman bencana gempa bumi, asesmen risiko bencana ini dilakukan jauh sebelum kejadian bencana terjadi sehingga dapat dijadikan sebagai pedoman dalam menyusun rencana aksi pengurangan risiko bencana. Salah satu instrumen standar yang dapat digunakan untuk memperkirakan potensi kerugian dan kerusakan akibat gempa bumi adalah HAZUS. Ini adalah sebuah platform yang dikembangkan oleh Federal Emergency Management Agency (FEMA) dan digunakan untuk melakukan asesmen risiko bencana. Tantala et al., (2008) melakukan asesmen risiko dan kerugian terhadap potensi gempa di Kota New York. Dalam studi tersebut, dibuat skenario dengan berbagai magnitude yang mungkin terjadi di New York. Hasil studi tersebut kemudian digunakan sebagai dasar dalam mengidentifikasi area-area serta bangunanbangunan yang memiliki risiko paling besar kemudian selanjutnya menyusun upayaupaya untuk menurunkan risiko tersebut. Hancilar et al., (2020) membuat estimasi kerugian akibat kejadian gempa di Istanbul. Bangunan yang dijadikan sebagai objek penelitian dalam studi Hancilar et al (2020) tersebut adalah bangunan tingkat menengah dan tinggi yang merupakan bangunan beton bertulang dengan sistem rangka pemikul momen. Studi tersebut membandingkan kerugian tahunan rerata (AAL) dengan rasio kerugian rerata (AALR).

HAZUS menggunakan analisis deterministik dan probabilistik untuk melakukan estimasi potensi kerusakan dan kerugian suatu wilayah akibat ancaman bencana gempa bumi (FEMA, 2004). 


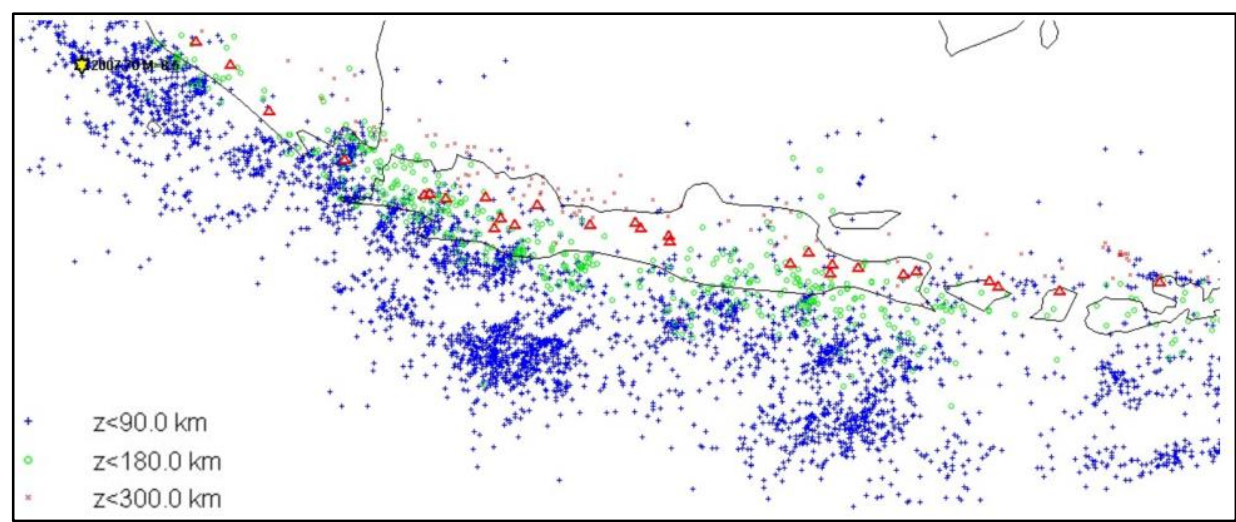

Gambar 1. Kejadian gempa bumi di sekitar Pulau Jawa tahun 1965-2019 (Erlangga, 2020)

Analisis deterministik bergantung pada hukum fisika atau korelasi yang dikembangkan melalui pengalaman atau pengujian untuk memprediksi hasil dari skenario bahaya tertentu. Sementara itu, analisis probabilistik mengevaluasi kemungkinan statistik (statistical likelihood) bahwa skenario bahaya tertentu akan terjadi dan berdampak pada wilayah yang diamati. Namun demikian, HAZUS dirancang untuk digunakan dalam asesmen risiko kerusakan bangunan-bangunan yang ada di Amerika Serikat. Oleh karena itu, diperlukan beberapa modifikasi dalam penerapan HAZUS jika platform ini akan digunakan di negara lain contohnya modifikasi kurva kapasitas bangunan (Aswandono, 2011; Bawono, 2011).

Pada tanggal 18 April 2018, sebuah gempa berkekuatan Mw 4,4 mengguncang Kabupaten Banjarnegara, Jawa Tengah, tepatnya di Kecamatan Kalibening. Data dari Pusat Gempa Nasional (2018) menunjukkan bahwa sumber gempa berada pada lokasi $7,21^{\circ} \mathrm{LS}$ dan $109,65^{\circ} \mathrm{BT}$ pada kedalaman $4 \mathrm{~km}$ di bawah permukaan tanah. Jarak episenter gempa terhadap Kecamatan Kalibening hanya kurang lebih 3 s.d. 4 km. Gempa ini dikategorikan sebagai gempa dangkal akibat aktivitas sesar lokal. Hasil pemodelan empirik fungsi atenuasi gempa dengan menggunakan persamaan Laurendeau et al. (dalam Douglas, 2018) menunjukkan nilai percepatan gempa maksimum ( $\mathrm{Sa}$ puncak) di wilayah Kalibening dan sekitarnya mencapai $0,58 \mathrm{~g}$. Menurut laporan dari BNPB Editorial (2018), gempa bumi ini menyebabkan 2 orang korban jiwa, 21 orang luka-luka, 316 rumah rusak, serta 2.104 jiwa harus mengungsi. Dari beberapa desa di Kecamatan Kalibening yang terdampak, Desa Kasinoman mengalami dampak yang paling parah.

Penelitian ini bertujuan untuk membandingkan perkiraan kerusakan yang dilakukan menggunakan HAZUS dengan observasi lapangan pasca kejadian gempa di Desa Kasinoman, Banjarnegara.

\section{KEJADIAN GEMPA BANJARNEGARA}

Dalam 2 dekade terakhir tercatat beberapa kali kejadian gempa di Banjarnegara yakni pada tahun 2009, 2011, dan yang terbaru, 2018. Gempa-gempa ini diakibatkan oleh sesar lokal namun magnitude yang dihasilkan terhitung minor karena kurang dari Mw 5.

Pada tanggal 18 April 2018, sebuah gempa berkekuatan Mw 4,4 mengguncang salah satu kecamatan di Banjarnegara, yakni Kecamatan Kalibening. Meskipun tergolong gempa minor, tetapi kerusakan yang diakibatkan tidak dapat dikatakan minor. Lebih dari 300 rumah dilaporkan mengalami kerusakan, Hal ini disebabkan oleh kedalaman gempa yang tergolong dangkal 
akibat sesar lokal serta jarak episenter yang dekat sehingga meskipun magnitude gempanya dibawah Mw 5 tetapi skala MMInya mencapai IV dan V. Sesar yang menjadi pemicu terjadinya gempa ini merupakan sesar baru yang sebelumnya belum teridentifikasi di peta gempa Indonesia. Karakteristik sesar yang menyebabkan gempa ini merupakan tipe sesar naik (reverse) (Handika \& Madlazim, 2020). Menurut BMKG, sesar ini terletak di sekitar sesar Kalibening-Wanayasa. Kondisi lapisan tanah di sebagian besar wilayah Kecamatan Kalibening yang tergolong sebagai tanah lunak juga membuat gelombang gempa mengalami amplifikasi.

Selain sumber gempa yang dangkal, kerusakan bangunan di Kecamatan Kalibening juga terjadi karena bangunanbangunan tersebut tidak dibangun sesuai kaidah bangunan tahan gempa (Saputra \& Faizah, 2019). Sebagai contoh, beberapa bangunan di lokasi kejadian tidak menggunakan material dengan kualitas yang baik. Hasil pengamatan di lapangan menunjukkan terdapat kadar lumpur dalam agregat yang relative tinggi hal ini terlihat dari warna campuran beton yang gelap kecoklatan (Gambar 2). Di samping itu, hasil pengamatan di lapangan juga menunjukkan bahwa sistem struktur bangunan kurang menyatu. Hal ini dibuktikan dengan kegagalan sambungan (joint) yang terjadi (Gambar 3).

\section{HAZUS (Hazard United States)}

HAZUS adalah singkatan dari Hazard United States. Ini merupakan metodologi yang dikembangkan oleh Federal Emergency Management Agency (FEMA) berkolaborasi dengan National Institute of Building Sciences (NIBS) untuk memperkirakan potensi kerusakan dan kerugian akibat bencana alam, seperti banjir, badai, dan gempa. Di Amerika, HAZUS digunakan oleh pemerintah pusat maupun daerah untuk keperluan mitigasi bencana, kesiapsiagaan, tanggap darurat serta pemulihan pasca bencana (Neighbors et al., 2013).

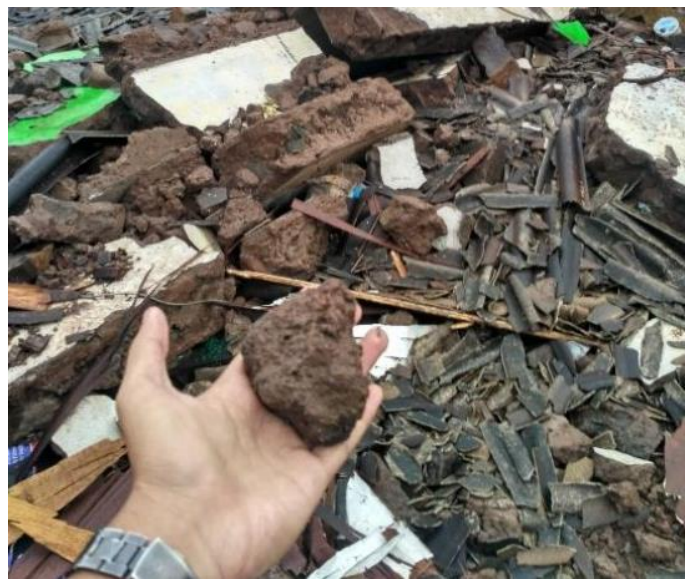

Gambar 2. Campuran beton yang kurang baik (Saputra \& Faizah, 2019)

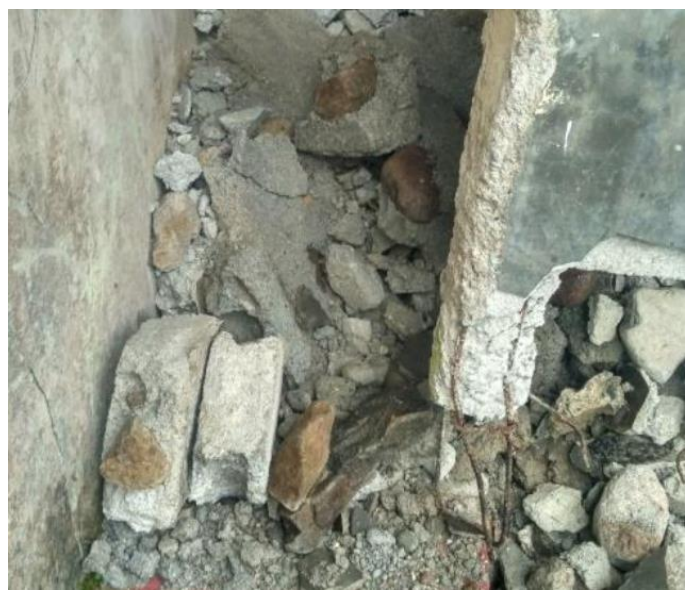

Gambar 3. Kegagalan sambungan (joint) (Saputra \& Faizah, 2019)

Estimasi kerusakan HAZUS didasarkan pada cakupan wilayah/kawasan bukan berdasarkan per unit bangunan (Aswandono, 2011). Artinya, HAZUS digunakan untuk melakukan estimasi kerusakan bangunanbangunan dalam satu kawasan tertentu. Oleh karena itu, inventarisasi bangunan yang ada di suatu kawasan wilayah yang ditinjau menjadi sangat penting. Inventarisasi yang dimaksud meliputi tipe bangunan, utilitas, fasilitas umum, batas wilayah, demografi, serta data ancaman. 
Untuk kasus bencana gempa, HAZUS mengkategorikan tipe kerusakan bangunan menjadi 5 kategori, yakni none (tidak ada kerusakan), slight (rusak minor), moderate (rusak sedang), extensive (rusak berat), complete (runtuh/roboh) (FEMA, 2020). Kelima kategori kerusakan tersebut didefiniskan dengan menggunakan penjelasan kerusakan secara deskriptif. Untuk menentukan level kerusakan suatu bangunan, HAZUS mempertimbangkan 2 (dua) aspek yakni kurva kapasitas (capacity curve) dan juga kurva kerentanan bangunan (fragility curve).

HAZUS telah digunakan sebagai alat untuk melakukan asesmen risiko akibat bencana sebagaimana ditunjukkan dalam Hancilar $e t$ al. (2020) dan Tantala et al. (2008). Di Indonesia sendiri, beberapa studi pernah dilakukan sebagaimana yang ditulis dalam Bawono (2016) dan Khalfan et al. (2012). Bawono (2016) melakukan studi perbandingan rumah tembokan di Bantul akibat gempa Yogyakarta 2006 dan menyimpulkan bahwa bangunan tembokan yang diteliti mendekati tipe bangunan HAZUS tipe URML (Unreinforced Masonry Bearing Walls).

\section{Kurva Kapasitas}

Kurva kapasitas adalah plot tahanan beban lateral sebuah bangunan sebagai fungsi dari perpindahan lateral (FEMA, 2015). Kurva kapasitas diturunkan dari plot gaya geser dasar ekivalen statis terhadap perpindahan bangunan (displacement). Kurva kapasitas yang dikembangkan oleh HAZUS didasarkan pada parameter desain rekayasa dan justifikasi teknik. Terdapat tiga titik kontrol dalam kurva kapasitas, yakni (1) kapasitas desain, (2) kapasitas luluh, dan (3) kapasitas ultimit

Dalam kasus rumah tembokan, bisa jadi titik-titik kontrol sebagaimana disebutkan di atas tidak dapat diketahui dengan pasti karena umumnya rumah-rumah tersebut bersifat getas. Rumah-rumah tembokan tidak memiliki perkuatan (frame) yang memadai sehingga kekuatannya tertumpu pada dinding tembok. Padahal, dinding merupakan komponen yang getas. Ketika mengalami guncangan akibat gempa, dinding akan mengalami gaya horizontal, baik pada sumbu kuat maupun sumbu lemahnya. Akibat tidak adanya perkuatan (frame) maka dinding ini akan mudah roboh saat kapasitasnya terlampaui (Gulati, 2006).

\section{Kurva Kerentanan}

Kurva kerentanan merupakan kurva yang menggambarkan probabilitas tercapai atau terlampaui berbagai level kerusakan akibat respons puncak bangunan (FEMA, 2015). Setiap kurva kerentanan ditentukan oleh nilai median dari parameter PESH (yaitu, spectral simpangan, spectral percepatan, PGA atau PGD) yang sesuai dengan ambang batas/level kerusakan dan oleh variabilitas yang terkait dengan level kerusakan tersebut. Probabilitas terlampaui sebuah level kerusakan ditentukan oleh persamaan (FEMA, 2020):

$$
P\left[d s \mid S_{d}\right]=\Phi\left[\frac{1}{\beta_{d s}} \ln \left(\frac{S_{d}}{S_{d, d s}}\right)\right]
$$

dimana:

$\begin{array}{ll}\text { Sd,ds } & \begin{array}{l}\text { nilai median dari spektral } \\ \text { simpangan ketika bangunan }\end{array} \\ \text { mencapai batas level kerusakan } \\ \text { standar deviasi dari spektral } \\ \text { simpangan ketika bangunan } \\ \text { mencapai batas level kerusakan } \\ \text { fungsi normal distribusi }\end{array}$

\section{METODE PENELITIAN}

Tahapan penelitian ini dibagi menjadi 3 (tiga), yakni tahap pra-survey, survey lapangan, dan pasca survey. Setiap tahap memiliki aktivitas yang berbeda-beda. Pada tahap pra-survey, aktivitas yang dilakukan meliputi penentuan lokasi penelitian, pengumpulan data administratif dari lokasi yang dipilih, pengumpulan data seismik (data gempa), membuat kuesioner pengamatan kerusakan, dan menentukan tipe-tipe bangunan yang ada di lokasi penelitian. Kuesioner digunakan sebagai panduan dalam melakukan observasi 
lapangan. Secara garis besar, kuesioner terdiri dari 2 bagian, yakni bagian 1 yang berisikan item-item untuk menentukan tipe bangunan serta bagian 2 yang berisikan item-item untuk menentukan tipe kerusakan menurut HAZUS. Pada tahap survey lapangan, aktivitas yang dilakukan adalah peninjauan kerusakan lapangan pascagempa serta pengisian kuesioner untuk mengetahui tingkat kerusakan bangunan serta untuk pembuatan inventerisasi bangunan (bulding inventory). Kemudian, di tahap akhir, aktivitas yang dilakukan adalah mengolah data survey kerusakan riil lapangan dan melakukan estimasi kerusakan menggunakan HAZUS kemudian membandingkannya.

\section{ANALISA DAN PEMBAHASAN}

\section{Tipe Bangunan di Desa Kasinoman}

HAZUS mengkategorikan bangunanbangunan menjadi 36 tipe berdasarkan komponen struktur dan rentang ketinggiannya. Komponen struktur dalam HAZUS dibagi menjadi 5 (lima) kategori, yakni struktur kayu, beton bertulang, beton precast, baja, serta tembokan (tanpa perkuatan). Untuk rentang ketinggian, HAZUS membaginya menjadi 3 (tiga) kategori, yakni tingkat rendah (1 sampai 3 lantai), tingkat menengah (4 sampai 7 lantai), serta tingkat tinggi (lebih dari 7 lantai). Dalam penelitian ini, hanya rumah tembokan yang tergolong tingkat rendah saja atau dalam kaidah HAZUS disebut dengan Unreinforced Masonry Bearing Walls Low-rise (URML). Secara sederhana, $U R M L$ dapat dipahami sebagai bangunan tembokan yang minimal terdiri dari 1 lantai, hingga 3 lantai tanpa perkuatan sloof, kolom, dan balok. Dalam penelitian ini, seluruh bangunan URML di Desa Kasinoman (317 bangunan) disurvei untuk kemudian ditentukan level kerusakannya menurut kriteria HAZUS.

\section{Kerusakan Aktual Bangunan URML di Desa Kasinoman}

HAZUS mengkategorikan level kerusakan bangunan menjadi 5 kategori, yakni tidak ada kerusakan, rusak minor, rusak sedang, rusak berat, dan roboh. Level kerusakan tersebut dijelaskan dengan menggunakan penjelasan kerusakan secara deskriptif.

Menurut Li dan Weigel (2006), level kerusakan di HAZUS ditentukan berdasarkan pendapat dan penilaian ahli, data pengujian, serta pengalaman. Untuk bangunan $U R M L$, penjelasan deskriptif mengenai level kerusakan dapat dilihat pada

Tabel 2. Setelah dilakukan survey kerusakan terhadap bangunan tipe URML di Desa Kasinoman sesuai panduan kerusakan HAZUS didapatkan hasil sebagaimana ditunjukkan dalam Tabel 1. Contoh hasil pengamatan di lapangan dapat dilihat pada Gambar 4.

Penyebab terjadinya kerusakan pada bangunan-bangunan ini antara lain adalah penggunaan material yang memiliki kualitas kurang baik. Di tambah lagi rumah-rumah tersebut tidak memiliki perkuatan beton bertulang yang memadai seperti yang dijelaskan dalam Saputra \& Faizah (2019). Akibatnya, bangunan bersifat getas sehingga ketika diguncang oleh gempa bangunan tersebut mengalami kerusakan bahkan roboh.

Tabel 1. Kerusakan bangunan $U R M L$ di Desa Kasinoman

\begin{tabular}{|c|c|c|}
\hline $\begin{array}{c}\text { Level } \\
\text { Kerusakan }\end{array}$ & $\begin{array}{c}\text { Jumlah } \\
\text { Bangunan }\end{array}$ & $\begin{array}{c}\text { Persentase } \\
(\%)\end{array}$ \\
\hline Tidak Rusak & 87 & 27.44 \\
\hline Ringan & 73 & 23.03 \\
\hline Sedang & 63 & 19.87 \\
\hline Berat & 39 & 12.30 \\
\hline Roboh & 55 & 17.35 \\
\hline Total & 317 & 100.00 \\
\hline
\end{tabular}




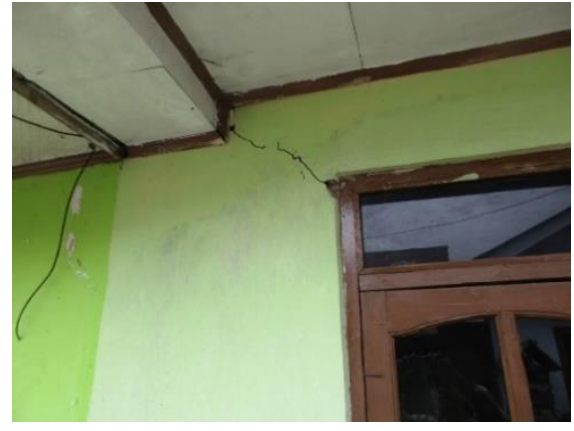

(a) Rusak Ringan

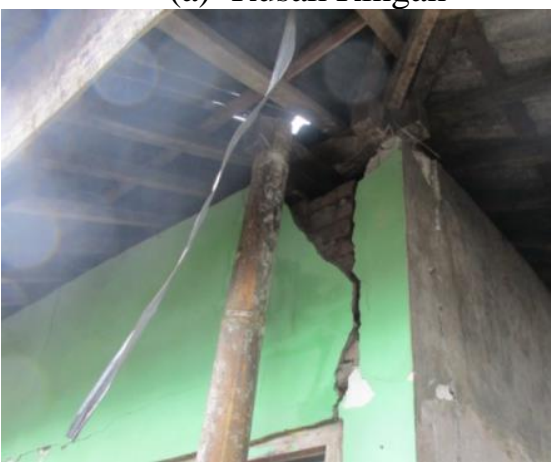

(b) Rusak Sedang

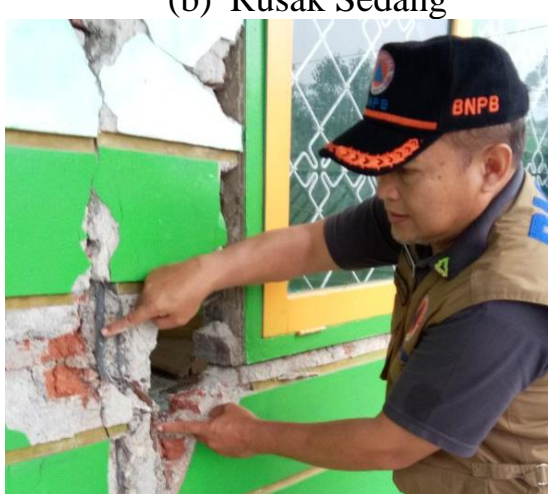

(c) Rusak Berat

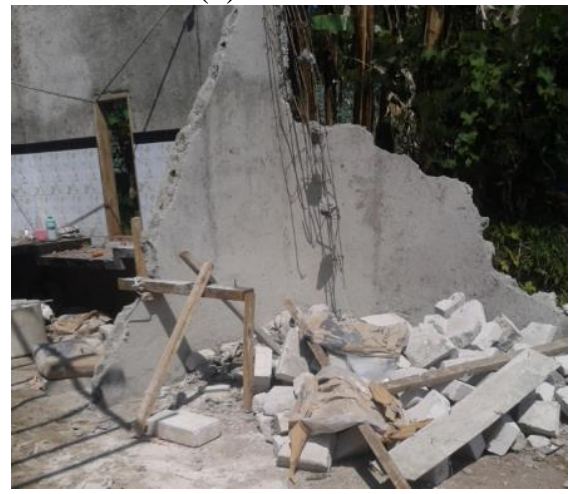

(d) Runtuh

Gambar 4. Contoh kerusakan rumah di Desa Kasinoman

\section{Estimasi Kerusakan Bangunan URML di Desa Kasinoman menggunakan HAZUS}

Parameter utama dalam memperkirakan kerusakan dengan menggunakan HAZUS adalah kurva kapasitas dan juga kurva kerentanan bangunan. HAZUS telah menetapkan nilai kurva kapasitas dan kurva kerentanan untuk tiap-tiap tipe bangunan. Tipe bangunan di Desa Kasinoman menurut klasifikasi HAZUS secara spesifik belum diketahui karena Indonesia belum mengelompokkan tipe-tipe bangunan sebagaimana HAZUS. Namun, berdasarkan penelitian Bawono (2011) tipe rumah tembok di Indonesia cenderung mendekati $U R M L$. Oleh karena itu, dalam perhitungan kerusakan prakiraan pada penelitian ini, bangunan di desa Kasinoman dikelompokkan menjadi tipe $U R M L$ sehingga penentuan kurva kapasitas serta kurva kerentannan bangunan mengacu pada kriteria bangunan URML HAZUS

Untuk menghubungkan antara kurva kapasitas dan kurva kerentanan bangunan diperlukan satu parameter lagi yakni respon puncak bangunan (peak building response). Artinya, dalam sebuah kejadian gempa tertentu suatu bangunan akan mengalami goncangan hingga mencapai respon puncak. Ketika respon puncak ini tercapai maka kerusakan akan terjadi

Respon puncak bangunan merupakan perpotongan antara kurva kapasitas dengan kurva spektrum respons (demand spectrum). Metode ini dikenal dengan metode Capacity-Spectrum sebagaimana tertulis dalam Applied Technology Council 40 (ATC-40) (FEMA, 2005).

Secara singkat, kurva demand spectrum dapat didefinisikan sebagai plot antara spektral simpangan $(S D)$ terhadap spektral percepatan (SA). Demand spectrum dalam penelitian ini dibuat dengan cara merekonstruksi kejadian gempa Banjarnegara 2018 menggunakan metode 
Tabel 2. Deskripsi Level Kerusakan Bangunan URML HAZUS (FEMA, 2020)

\begin{tabular}{|c|l|}
\hline Level Kerusakan & \multicolumn{1}{c|}{ Deskripsi } \\
\hline Ringan & $\begin{array}{l}\text { Retakan garis rambut anak tangga diagonal pada permukaan dinding } \\
\text { pasangan bata; retakan yang lebih besar di sekitar bukaan pintu dan } \\
\text { jendela di dinding dengan proporsi bukaan yang besar; pergerakan } \\
\text { ambang pintu; retakan di dasar tembok pembatas. }\end{array}$ \\
\hline Sedang & $\begin{array}{l}\text { Sebagian besar permukaan dinding menunjukkan retakan diagonal; } \\
\text { beberapa dinding menunjukkan retakan diagonal yang lebih besar; } \\
\text { dinding pasangan bata mungkin memiliki pemisahan yang terlihat } \\
\text { dari diafragma; retakan tembok pembatas yang signifikan; beberapa } \\
\text { pasangan bata mungkin jatuh dari dinding atau tembok pembatas. }\end{array}$ \\
\hline Berat & $\begin{array}{l}\text { Pada bangunan dengan bukaan dinding yang relatif luas, sebagian } \\
\text { besar dinding mengalami keretakan yang parah. Beberapa tembok } \\
\text { pembatas dan dinding ujung atap pelana telah runtuh. Balok atau } \\
\text { rangka mungkin telah bergerak relatif terhadap penyangganya. }\end{array}$ \\
\hline Roboh & $\begin{array}{l}\text { Struktur telah runtuh atau dalam bahaya runtuh karena kerusakan } \\
\text { dinding di dalam atau di luar bidang. Diperkirakan sekitar 25\% dari } \\
\text { total luas bangunan URM yang rusak total akan runtuh. }\end{array}$ \\
\hline
\end{tabular}

deterministik atau fungsi atenuasi berdasarkan data yang tersedia.

Spektra percepatan $(S A)$ diturunkan dari Ground Motion Prediction Equation (GMPE) yang melibatkan berbagai parameter diantaranya tipe batuan, jarak episenter, kondisi tanah setempat, dan lainlain (Pratiwi et al., 2019). Terdapat banyak fungsi atenuasi atau GMPE sebagaimana dirangkum oleh Douglas (2018). Dalam penelitian tersebut, dari sekian banyak GMPE, dipilih satu GMPE yang dianggap dapat mewakili kejadian gempa Banjarnegara 2018, yakni fungsi atenuasi yang diusulkan oleh Laurendeau et al. (2013). GMPE yang diusulkan tersebut, disusun berdasarkan kejadian gempa yang memiliki magnitude diatas M5,6 maupun dan juga di bawah M5,6. Kemudian, gempa yang diperhitungkan juga hanya gempa dengan kedalaman kurang dari $25 \mathrm{~km}$ (gempa dangkal) dan juga memperhitungkan beberapa gempa yang tergolong near source $(<10 \mathrm{~km})$. Beberapa kriteria tersebut sesuai dengan data gempa Banjarnegara 2018 yang memiliki magnitude M4,4 di kedalaman 4 $\mathrm{km}$ serta berjarak kurang lebih $3 \mathrm{~km}$ dari lokasi penelitian.

Setelah mendapatkan demand spectrum untuk Desa Kasinoman, respon puncak bangunan $U R M L$ di wilayah tersebut dapat dicari dengan cara menggabungkan (overlay) kurva kapasitas bangunan URML dengan kurva demand spectrum. Titik perpotongan antara kedua kurva tersebut merupakan respon puncak yang selanjutnya digunakan untuk menentukan probabilitas kerusakan untuk setiap level kerusakan bangunan. Gambar 5 menunjukkan respon puncak dari bangunan URML di Desa Kasinoman akibat Gempa Banjarnegara 2018 dimana nilai spektral simpangannya $(S D)$ ada di angka 0,51 inci.

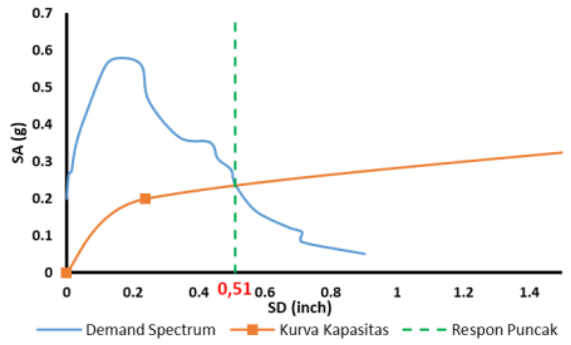

Gambar 5. Respon puncak bangunan $U R M L$ 
Nilai respon puncak bangunan ini kemudian digunakan untuk menentukan probabilitas kerusakan bangunan pada berbagai level kerusakan dengan cara menggabungkannya dengan kurva kerentanan bangunan URML. Plot respon puncak bangunan dan kurva kerentanan bangunan URML dapat dilihat pada Gambar 6. Dari Gambar 6 dapat diketahui bahwa probabilitas kerusakan bangunan URML pada setiap level kerusakan adalah sebagaimana ditampilkan dalam Tabel 3.

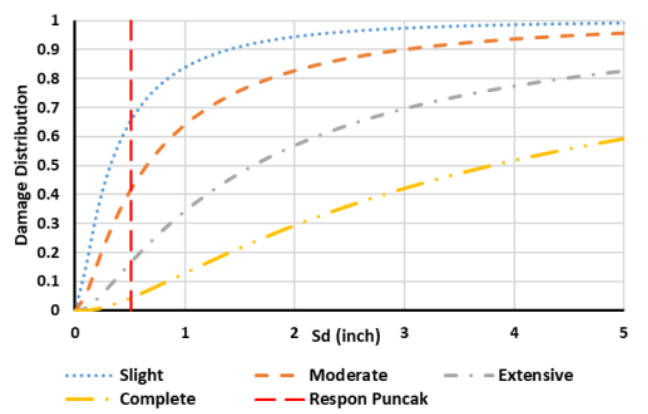

Gambar 6. Plot kurva kapasitas terhadap respon puncak bangunan

Tabel 3. Persentase perkiraan kerusakan URML oleh HAZUS

\begin{tabular}{|c|c|c|}
\hline $\begin{array}{c}\text { Level } \\
\text { Kerusakan }\end{array}$ & \multicolumn{2}{|c|}{ Kerusakan } \\
\cline { 2 - 3 } & Desimal & $\begin{array}{c}\text { Persentase } \\
(\%)\end{array}$ \\
\hline Tidak Rusak & 0.3364 & 33.64 \\
\hline Ringan & 0.2379 & 23.79 \\
\hline Sedang & 0.2538 & 25.38 \\
\hline Berat & 0.1255 & 12.55 \\
\hline Roboh & 0.0464 & 4.64 \\
\hline Total & 1.00 & 100.00 \\
\hline
\end{tabular}

Perbandingan antara Kerusakan Aktual dengan Kerusakan Perkiraan

Kerusakan aktual dan kerusakan perkiraan untuk bangunan URML di Desa Kasinoman akibat Gempa Banjarnegara 2018 telah dihitung secara terpisah. Hasilnya, pada masing-masing kerusakan didapatkan persentase untuk setiap level kerusakan mulai dari tidak rusak, ringan, sedang, berat, dan roboh. Perbandingan antara keduanya disajikan dalam Gambar 7.

Dari Gambar 7 dapat dilihat bahwa untuk level kerusakan ringan dan berat terdapat selisih kurang dari $1 \%$ antara kerusakan aktual dan kerusakan perkiraan HAZUS. Untuk level kerusakan none dan moderate terdapat selisih $6,2 \%$ dan $5,5 \%$ dimana persentase kerusakan yang didapatkan dari estimasi HAZUS menunjukkan persentase yang lebih tinggi. Untuk level kerusakan roboh selisih antara kerusakan aktual dan perkiraan HAZUS menunjukkan nilai yang terbesar yakni $12,71 \%$ dimana persentase kerusakan aktual di lapangan lebih tinggi dibandingkan estimasi HAZUS.

Untuk melihat persentase kerusakan secara keseluruhan baik kerusakan aktual maupun kerusakan perkiraan, dilakukan perhitungan rasio kerusakan rata-rata (mean damage ratio, $M D R)$. MDR merupakan tingkat kerusakan yang digunakan untuk memperkirakan kerugian akibat sebuah kejadian bencana. Semakin tinggi nilai $M D R$, semakin tinggi biaya yang perlu dikeluarkan untuk perbaikan. $M D R$ dihitung dengan menggunakan persamaan Hwang (dalam Aswandono, 2011) berikut ini.

$$
M D R=\sum\left(P_{d s} x C D F\right)
$$

dimana:

$P d s \quad$ diskrit kerusakan bangunan

CDF Central Damage Factor untuk tiap level kerusakan

Perhitungan $M D R$ untuk kerusakan aktual dan kerusakan perkiraan HAZUS ditampilkan dalam Tabel 4 dan Tabel 5. Dari kedua tabel tersebut dapat diketahui bahwa nilai $M D R$ untuk kerusakan aktual $(20,40 \%)$ lebih besar dibandingkan dengan nilai $M D R$ untuk kerusakan perkiraan 


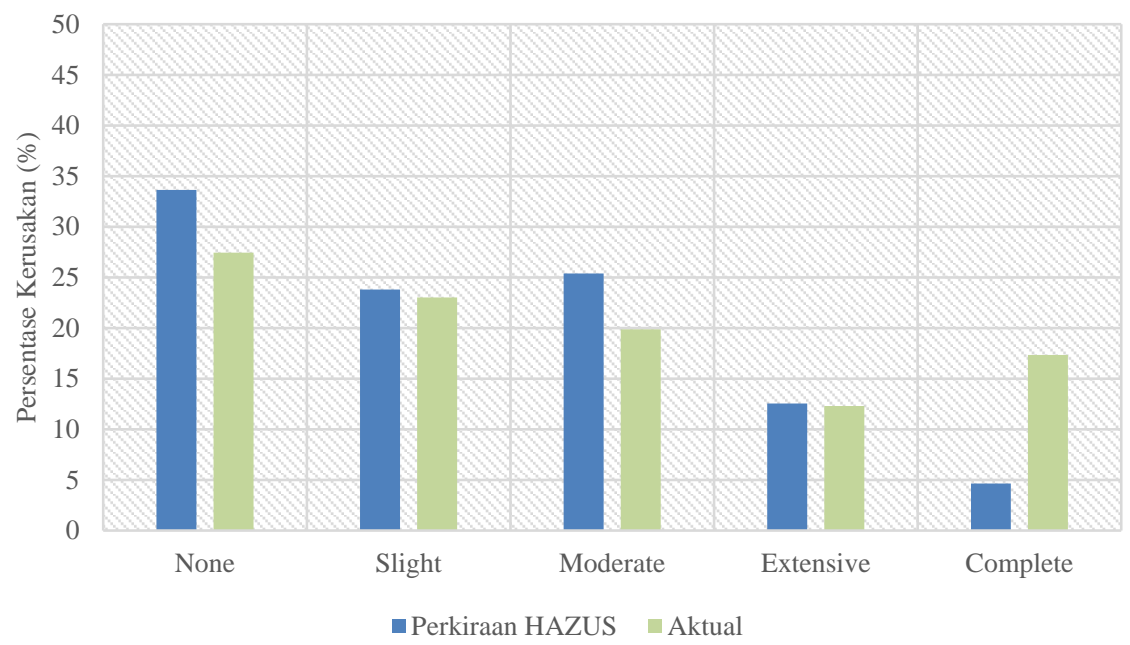

Gambar 7. Perbandingan kerusakan aktual dan perkiraan HAZUS

HAZUS $(11,66 \%)$. Oleh karena semakin besar nilai MDR, semakin besar tingkat kerusakan, hal ini mengindikasikan bahwa bangunan URML yang ada di Desa Kasinoman memiliki performa yang lebih buruk dibandingkan dengan URML HAZUS. Meskipun keduanya sama-sama merupakan bangunan tembokan tanpa perkuatan namun keduanya memiliki tingkat kerusakan yang berbeda. Dengan kata lain, penggunaan parameter kurva kapasitas dan kurva kerentanan bangunan URML standar HAZUS tidak begitu cocok apabila digunakan secara langsung untuk $U R M L$ di Desa Kasinoman. Hal ini bisa jadi disebabkan oleh kualitas bangunan yang berbeda. HAZUS dikembangkan oleh Amerika berdasarkan pengalamanpengalaman yang ada disana. Di Amerika Serikat, kualitas bangunan bisa dikatakan seragam dan memenuhi persyaratan. Sebaliknya, kualitas bangunan di Indonesia antara satu bangunan dengan bangunan lainnya bisa sangat berbeda. Indonesia sendiri sudah menerbitkan buku panduan rumah sederhana yang tahan gempa seperti Buku Saku Persyaratan Pokok Rumah yang Lebih Aman pada tahun 2009. Namun, sebagian besar rumah yang ada di Desa
Kasinoman dibangun jauh sebelum buku tersebut diterbitkan sehingga rumah-rumah tersebut dibangun tanpa mengikuti kaidah bangunan tahan gempa.

Tabel 4. MDR untuk kerusakan aktual

\begin{tabular}{|c|c|c|c|}
\hline $\begin{array}{c}\text { Level } \\
\text { Kerusakan }\end{array}$ & $\begin{array}{c}\text { Diskrit } \\
\text { Kerusakan }\end{array}$ & $\begin{array}{c}\text { CDF } \\
(\%)\end{array}$ & $\begin{array}{c}\text { Persentase } \\
\text { Kerusakan } \\
(\%)\end{array}$ \\
\hline Tidak Rusak & 0,27 & 0,05 & 0,01 \\
\hline Ringan & 0,23 & 2,55 & 0,59 \\
\hline Sedang & 0,20 & 12,5 & 2,48 \\
\hline Berat & 0,12 & 35 & 4,31 \\
\hline Roboh & 0,17 & 75 & 13,01 \\
\hline \multicolumn{3}{|c|}{$M D R$} & 20,40 \\
\hline
\end{tabular}

Tabel 5. MDR untuk kerusakan perkiraan

\begin{tabular}{|c|c|c|c|}
\hline $\begin{array}{c}\text { Level } \\
\text { Kerusakan }\end{array}$ & $\begin{array}{c}\text { Diskrit } \\
\text { Kerusakan }\end{array}$ & $\begin{array}{c}\text { CDF } \\
(\%)\end{array}$ & $\begin{array}{c}\text { Persentase } \\
\text { Kerusakan } \\
(\%)\end{array}$ \\
\hline $\begin{array}{c}\text { Tidak } \\
\text { Rusak }\end{array}$ & 0,34 & 0,05 & 0,02 \\
\hline Ringan & 0,24 & 2,55 & 0,61 \\
\hline Sedang & 0,25 & 12,5 & 3,17 \\
\hline Berat & 0,13 & 35 & 4,39 \\
\hline Roboh & 0,05 & 75 & 3,48 \\
\hline \multicolumn{3}{|c}{$M D R$} & 11,66 \\
\hline
\end{tabular}




\section{KESIMPULAN DAN SARAN}

\section{Kesimpulan}

Hasil penelitian ini menunjukkan Mean Damage Ratio $(M D R)$ kerusakan aktual bangunan $U R M L$ ada di angka 20,40\% sedangkan kerusakan perkiraan menunjukkan angka 11,66\%. Artinya, performa bangunan URML di Desa Kasinoman, jika dibandingkan dengan bangunan URML standar HAZUS, memiliki performa yang lebih buruk. Dengan kata lain, penggunaan URML HAZUS untuk kasus yang ada di Desa Kasinoman kurang sesuai. Hal ini bisa jadi disebabkan oleh perbedaan kurva kapasitas serta kurva kerentanan bangunan. Nilai kurva kapasitas dan kurva kerentanan URML standar HAZUS ditentukan berdasarkan pengalaman terdahulu, riset, justifikasi ahli, dan pengalaman lapangan di Amerika dimana bangunan-bangunan yang ada disana cenderung seragam dari sisi kualitas serta telah mengikuti persyaratan (code) yang berlaku sehingga menunjukkan performa (kurva kapasitas dan kerentanan) yang lebih baik. Di sisi lain, bangunan di Desa Kasinoman terindikasi tidak sesuai dengan kaidah bangunan tahan gempa seperti penggunaan material berkualitas buruk, tidak tersedianya satu atau lebih elemen perkuatan (frame), serta detil perkuatan yang buruk sehingga menunjukkan performa (kurva kapasitas dan kerentanan) yang lebih buruk.

\section{Saran}

Diperlukan riset lebih lanjut mengenai kurva kapasitas bangunan URML di Desa Kasinoman secara khusus berdasarkan observasi kerusakan pasca kejadian gempa, agar didapatkan nilai kurva kapasitas maupun kurva kerentanan tersendiri sesuai dengan bangunan yang ada di wilayah tersebut.

\section{DAFTAR PUSTAKA}

Aswandono, B. (2011). "Building Replacement Cost for Seismic Risk
Assessment in Palbapang Village, Bantul Sub-District, Yogyakarta Building Replacement Cost For Seismic Risk Assessment in Palbapang, Indonesia". Universitas Gadjah Mada.

Bawono, A. S. (2011). "Kajian Bangunan Di Indonesia Dengan Amerika (Studi Kasus Rumah Di Bantul)". Inersia, 7(1), 85-95 https://doi.org/10.21831/inersia.v7i1.3 706.

Bawono, A. S. (2016). "Studi Kerentanan Bangunan Akibat Gempa : Studi Kasus Perumahan Di Bantul". Semesta Teknika, 19(1), 90-97.

BMKG. (2018). "Press Release Gempabumi Banjarnegara, M 4.4, Rabu 18 April 2018, 13:28:38 WIB". https://cdn.bmkg.go.id/web/PRESSRELEASE_Banjarnegara_-18-April1-2018.pdf

BNPB Editorial. (2018). "2 Tewas, 21 Luka, 316 Rumah Rusak dan 2.104 Jiwa Mengungsi Akibat Gempa di Banjarnegara". https://bnpb.go.id/berita/2-tewas-21luka-316-rumah-rusak-dan-2104-jiwamengungsi-akibat-gempa-dibanjarnegara

Douglas, J. (2018). "Ground motion prediction equations 1964-2018". Departmen of Civil and Environmental Engineering, University of Stratchlyde.

Erlangga, W. (2020). "Karakteristik Dan Parameter Subduksi Sumber Gempa Pulau Jawa". Teknisia, XXV(2), 30-40. https://doi.org/10.20885/teknisia.vol2 5.iss2.art4.

FEMA. (2004). "Using HAZUS-MH for Risk Assessment". (Issue August).

FEMA. (2005). "Improvement of Nonlinear Static Seismic Analysis Procedures. In FEMA 440, Federal Emergency Management Agency, Washington $D C^{\prime \prime}$. (Vol. 440, Issue June). http://scholar.google.com/scholar?hl= en\&btnG=Search\&q=intitle:Improve 
ment+of+Nonlinear+Static+Seismic+ Analysis+Procedures\#2\%5Cnhttp://sc holar.google.com/scholar?hl=en\&btn $\mathrm{G}=$ Search\&q=intitle:440,+Improveme $\mathrm{nt}+\mathrm{of}+$ nonlinear+static+seismic+analy sis+procedures\#2

FEMA. (2015). "Rapid Visual Screening of Buildings for Potential Seismic Hazards: Supporting Documentation". Federal Emergency Management Agency.

https://books.google.co.id/books?id= UnmvD74y9uQC

FEMA. (2020). "HAZUS. Earthquake Model, Technical Manual". Federal Emergency Management Agency, Washington DC., October. https://www.fema.gov/

Gulati, B. (2006). "Earthquake Risk Assessment of Buildings: Applicability of HAZUS in Dehradun, India".

Hancilar, U., Sesetyan, K., \& Cakti, E. (2020). "Comparative earthquake loss estimations for high-code buildings in Istanbul". Soil Dynamics and Earthquake Engineering, 129 (May 2019), 105956. https://doi.org/10.1016/j.soildyn.2019. 105956

Handika, M. S. D., \& Madlazim (2020). No Title. Jurnal Inovasi Fisika Indonesia (IFI), 09(03), 1-6.

IFRC. (2015). "Sendai Framework for DRR". March, 25. http://www.unisdr.org/we/inform/term inology

Khalfan, M., Tait, M. J., \& El-Dakhakhni, W. W. (2012). "Proposed Technique for Seismic Vulnerability Evaluation of Single Storey Unreinforced Masonry Residential Buildings in Developing Countries". 15th International Brick and Block Masonry Conference, 10.
Li, J., \& Weigel, T. A. (2006). "Damage States for Reinforced CMU Masonry Shear Walls". Advances in Engineering Structures, Mechanics \& Construction (pp. 111-120). Springer.

Neighbors, C. J., Cochran, E. S., Caras, Y., \& Noriega, G. R. (2013). "Sensitivity Analysis of FEMA HAZUS Earthquake Model: Case Study from King County, Washington". Natural Hazards Review, 14(2), 134-146. https://doi.org/10.1061/(asce)nh.15276996.0000089

Pratiwi, D. S., Teguh, M., \& Pawirodikromo, W. (2019). "An Implementation of the HAZUS Method for Estimating Potential Damage of Residential Houses at Pacitan Subdistrict, East Java, Indonesia due to Earthquake". MATEC Web of Conferences, 280, 01008. https://doi.org/10.1051/matecconf/201 928001008

Saputra, E., \& Faizah, R. (2019). "Kajian Kerusakan Bangunan Sederhana Pasca Gempa Banjarnegara 18 April 2018". Agregat, 4(1). https://doi.org/10.30651/ag.v4i1.2816

Spence, R. (2004). "Earthquake protection: the need for legislation to strengthen high-risk buildings". 13th World Conference on Earthquake Engineering, 2082.

Tantala, M. W., Nordenson, G. J. P., Deodatis, G., \& Jacob, K. (2008). "Earthquake loss estimation for the New York City Metropolitan Region". Soil Dynamics and Earthquake Engineering, 28(10-11), 812-835. https://doi.org/10.1016/j.soildyn.2007. 10.012

Widodo. (2012). "Seismologi Teknik dan Rekayasa Kegempaan". Pustaka Pelajar. 